OPEN ACCESS

Edited by:

Barry Antonio Costa-Pierce, University of New England,

United States

Reviewed by:

Michael Fabinyi,

Climate, Society and Environment Research Centre University of Technology Sydney, Australia Brooks A. Kaiser,

University of Southern Denmark, Denmark

*Correspondence:

Maiken Bjørkan

maiken.bjorkan@nforsk.no

Specialty section:

This article was submitted to Agroecology and Ecosystem Services,

a section of the journal

Frontiers in Sustainable Food Systems

Received: 14 October 2021

Accepted: 24 January 2022

Published: 18 February 2022

Citation:

Bjørkan M and Billing S-L (2022)

Commercial Seaweed Cultivation in

Scotland and the Social Pillar of

Sustainability: A Q-Method Approach

to Characterizing Key Stakeholder

Perspectives.

Front. Sustain. Food Syst. 6:795024.

doi: 10.3389/fsufs.2022.795024

\section{Commercial Seaweed Cultivation in Scotland and the Social Pillar of Sustainability: A Q-Method Approach to Characterizing Key Stakeholder Perspectives}

\author{
Maiken Bjørkan ${ }^{1 *}$ and Suzannah-Lynn Billing ${ }^{2}$ \\ ${ }^{1}$ Nordland Research Institute, Bodø, Norway, ${ }^{2}$ Scottish Association for Marine Science, Oban, Scotland
}

Finding the right way to move forward with seaweed cultivation requires the relevant stakeholders to reach agreement on what goals/limits to set and subsequently what measures should be taken to achieve them. Using a Q-method approach and an analytical framework based on in-put legitimacy and the four pillars of sustainability, we discuss the answers of a diverse set of stakeholders to the question: how should commercial seaweed cultivation in Scotland develop? Our results reveal three main discourses. The first focused on environmental and social sustainability, the second on accessing global markets, economic and environmental sustainability and the third prioritized jobs and social and institutional sustainability. The areas of consensus across the factors included the perception that large-scale and multi-national owned farms are not the ideal model for development of the industry in Scotland. All participants advised that the current regulatory regime for seaweed cultivation requires improvement. These results are discussed within the analytical framework and a prediction of the factors required to establish a legitimate seaweed cultivation industry in Scotland is presented.

Keywords: legitimacy, Q method, seaweed, sustainability, coastal zone management

\section{INTRODUCTION}

The need to source materials for food, fuel, chemical and pharmaceutical industries from sustainable supplies is growing. The marine environment has long provided these resources, with seaweeds supplying everything from alginates and carrageenans for toothpaste through to salad for dinner. The Food and Agricultural Organization of the United Nations analysis shows that there has been a global increase in seaweed production of 7.6\% between 2004 and 2014, much of which is based in China (FAO, 2018). However, the opportunities that seaweed presents as a potentially sustainable resource have been recognized across Europe, which has led to several research projects and companies exploring commercialization (Van den Burg et al., 2019; Froehlich et al., 2019). While many seaweeds can be harvested from the wild there is a growing opposition to kelp harvesting specifically, led by fishers, environmentalists, and local communities. Hence, countries in the North Atlantic, both east and west, look to seaweed cultivation as a solution. 
While seaweed cultivation holds potential for "blue growth" (e.g., Froehlich et al., 2019), it also generates new challenges as it is set within the context of escalating competition for the use of ocean and coastal areas and resources. As such, there is the possibility that this newly emerging activity could add to conflicts in the coastal zone that are likely to relate to all aspects of sustainability; natural, economic, social and institutional. For example, large-scale cultivation can have a different impact on the biophysical marine environment than small-scale cultivation. However, as this is a new industry in Europe, the effects on the environment at any scale are still uncertain (Campbell et al., 2019). Local ownership has the potential to generate different benefits for local communities than multinational ownership, both creating varied but strong links between social and economic sustainability. Finally, how the sector should be organized in terms of regulation will impact issues such as who is included in governance processes, and where accountability lies if something goes wrong-be it environmental, social, or economic. Finding the right way to move forward with seaweed cultivation requires that the relevant stakeholders reach compromise on what goals to aim for and subsequently what measures should be taken to achieve them (Raadgever et al., 2008). In order to realize this, it is pivotal to elicit stakeholders' perspectives to understand what a "successful" seaweed cultivation sector would look like.

Taking a constructivist approach to these issues and using Q methodology, we explore stakeholders' perception of seaweed cultivation within the context of the concept of legitimacy, described in more detail later on in this paper. Legitimacy is argued as key to ensuring sustainable management of resources in line with good governance ideals, and to safeguard the stability of social, political and economic systems (Suchman, 1995). We use Scotland as a case study, as the Scottish government has identified seaweed cultivation as an industry that can contribute to the blue economy with particular potential for rural, island and coastal communities (The Scottish Government, 2017). In addition, the West Coast is already host to several test sites and small-scale commercial operations. In this study, we explore how stakeholders, that is, seaweed cultivators, scientists, regulators, supply-chain services and interested community representatives, view the current processes around seaweed cultivation and its development. We investigate if the process of establishing seaweed cultivation as a new industry in the coastal zone is perceived as legitimate or not, and what it will take to achieve legitimacy. In order to answer this, we ask: how should commercial seaweed cultivation in Scotland develop?

In the following sections, we will present the current context of seaweed cultivation in Scotland, including the consenting regime and relevant social and legal processes it interacts with, before describing the theoretical framework we used to conduct the study and analyze the results.

\section{CURRENT SEAWEED CULTIVATION CONSENTING REGIME}

The aquaculture consenting procedure in Scotland is currently characterized by the marine planning regime, comprised of national and supranational frameworks (see Figure 1) and several different national (Scottish) and regional (county level) authorities, government agencies and licenses (see Table 1).

Prior to 2016 there were no commercially operating seaweed farms in Scotland, and no regulations to suit. However, in 2012 the Scottish Government conducted a Strategic Environmental Assessment for seaweed cultivation (Marine Scotland, 2012) and in 2017 concluded a consultation process started in 2013, through the publication of the Scottish Seaweed Cultivation Policy Statement (The Scottish Government, 2017). The Statement sets out seven policies (P), of which the first and fifth are of particular relevance to this study. Policy one asserts that "In principal, the Scottish Government is supportive of smallmedium farm seaweed cultivation... " subject to planning and environmental regulation. Policy five states that "Other marine users and activities should be considered in the siting of farms". The other five policies relate to biosecurity (P2), location of farms in relation to water quality (P3), survivability and suitability of equipment (P4), site suitability including visual impacts (P6), and general support for integrated multi-trophic aquaculture (P7).

Although seaweed cultivation is viewed by government and some regional level organizations as an industry that has the potential to expand in a sustainable manner (Argyll Bute Council, 2017; The Scottish Government, 2017), it will be competing for space in an already busy inshore marine environment. In addition, there are currently industries operating in this area which are not identified as competitors by the Scottish National Marine Plan but are by local communities and businesses. For example, perceived negative impacts on the tourism industry are often a cited as a reason for objecting to planning applications for finfish aquaculture (Billing, 2018). Although there are efforts currently underway to improve understanding around the potential impacts that seaweed cultivation might have in Scottish waters (see for example the H2020 projects Genialg and MacroFuels), it is currently not known what scale of seaweed cultivation is required for economic feasibility (Van den Burg et al., 2016), what environmental impacts different scales might imply (Campbell et al., 2019), or the potential conflicts or synergies that might arise in relation to other users of the sea and local communities that will host the industry.

\section{LOCAL CONTEXT: SEAWEED HARVESTING AND CULTIVATION}

Kelp forests around the UK are biodiverse and provide several ecosystem services including: habitat for species of inherent and commercial value (e.g., European lobster, Atlantic cod, Pollock, seals, and otters); coastal defense through wave attenuation and dampening and; health and wellbeing benefits for humans through interaction, cultural significance and economic reliance (Smale et al., 2013). In 2017, a Scottish company submitted a proposal to harvest up to 33,000 tons of kelp (Laminaria hyperborea) per year from coastal waters in western Scotland. The kelp was to be used as a raw material for the production of

1 "Small to medium" scale farms are classified by the Scottish Government as 0-50x200 meter lines (The Scottish Government, 2017). 


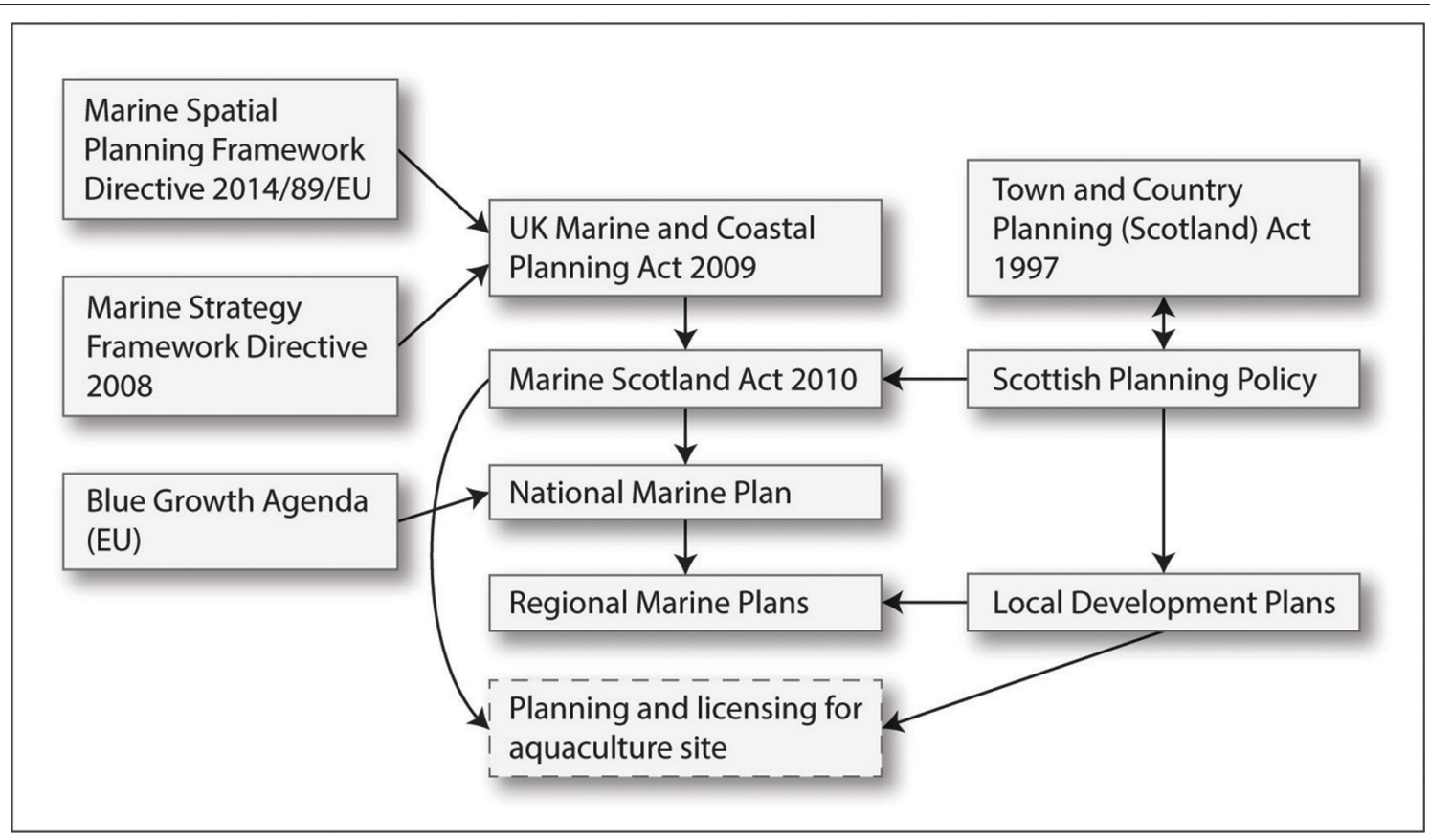

FIGURE 1 | Rough guide to the marine planning regime in Scotland as described by Brooker et al. (2019) in addition to Billing (2018). Dotted lines show processes that include local level stakeholder and community engagement.

biomaterials including alginate and nanocellulose. The proposal was opposed by fishers, fish-farmers, hand-harvesters of seaweed, coastal and island communities, the general public, public figures (including Sir David Attenborough) and some environmental NGOs. Opposition included a social media campaign, media coverage, and a petition signed by 14,000 people.

Following this public controversy, several amendments were made to the Crown Estate Bill under consideration at that time, by the Scottish Parliament. The final amendment (14ZA) was accepted by Parliament on 21 November 2018 and prohibits any mechanical removal (for commercial purposes) of 5 species of "wild kelp from the seabed" that "would inhibit the regrowth of the individual plant". Listed species were Laminaria hyperborea, $L$. digitata, Saccharina latissimi, Saccorhiza polyschides and Alaria esculenta (Scottish Parliament, 2018). Given that the main meristem of L. hyperborea is at the top of the stipe (i.e., the base of the frond) (Burrows et al., 2018), this effectively outlaws mechanical harvesting of this species for its alginate-rich stipe.

Laminaria hyperborea can be farmed, but existing strains have a low yield of alginate under farm conditions. Saccorhina latissima is currently farmed and has a good content of alginate. However, providing the biomass needed for commercial purposes would require farms covering at least $30 \mathrm{~km}^{2}$ (at harvestable densities of 10 tons per hectare) (Bak et al., 2018). However, the Scottish Seaweed Cultivation Policy Statement determines support for seaweed cultivation in farms of up to 1 hectare. The Statement does not consider large sites on the grounds that they are not at present technically, environmentally or economically feasible (The Scottish Government, 2017). In this context, a review of the "regulatory regime of all kelp harvesting activity up to and including farming", was announced on 20 November 2018 by the Scottish Environmental Secretary, Roseanna Cunningham and is currently underway (The Scottish Government, 2019b).

\section{THEORETICAL FRAMEWORK}

\section{Legitimacy}

Legitimacy theory is concerned with understanding what makes something-a process, an institution, a governance structure, in our case an industrial activity and its regulation-acceptable within a socially constructed system (Suchman, 1995). It plays a key role in policy development and democracy as is found in a large body of literature within anthropology, philosophy, organizational studies and more (e.g., Weber, 1946; Jentoft, 2000; Wilson, 2009; Bjørkan, 2011). In general, legitimacy is assumed to induce compliance, encourage participation and lower costs to those seeking it. Suchman (1995) defines legitimacy as:

\footnotetext{
“... a generalized perception or assumption that the actions of an entity are desirable, proper, or appropriate within some socially constructed system of norms, values, beliefs and definitions." (Suchman, 1995, p. 574)
}

Given the aim of this article is to try and understand the characteristics that might make a seaweed cultivation industry in Scotland acceptable to stakeholders and local communities, within, at the time of writing, a limited regulatory framework, this definition of legitimacy fits well. However, we choose to take the approach of Scharpf (1999) in trying to understand the requirements of legitimacy (in-put and out-put), rather than the four typologies described by Suchman (1995). Our 
TABLE 1 | The current consenting regime for cultivating seaweed in Scotland.

\begin{tabular}{|c|c|c|c|}
\hline Application & $\begin{array}{l}\text { Authorizing } \\
\text { regulator/monitoring } \\
\text { agency }\end{array}$ & Legislation & Additional information \\
\hline Marine license & $\begin{array}{l}\text { Marine Scotland Licensing } \\
\text { Operations Team (MS-LOT) }\end{array}$ & Marine Scotland Act 2010 & $\begin{array}{l}\text { The application requires an assessment of areas of concern such as Special } \\
\text { Areas of Conservation, Special Protected Areas, Special Sites of Scientific } \\
\text { Interest, Marine Protected Areas, Ramsar sites, shellfish harvesting areas, and } \\
\text { marine archaeology. It might also require a pre-application public consultation. If } \\
\text { so, a report of the consultation should be submitted with the application. This } \\
\text { should include those who were consulted, when, where, and how. MS-LOT will } \\
\text { consult with statutory consultees including the Northern Lighthouse Board, } \\
\text { statutory Harbor Authority, Scottish Natural Heritage, Scottish Environmental } \\
\text { Protection Agency, Historic Scotland, Royal Society for the Protection of Birds, } \\
\text { and the relevant District Salmon and Fishery Board. A Marine License is normally } \\
\text { granted for } 6 \text { years. Determination of an application is } 14 \text { weeks, although it can } \\
\text { take longer. }\end{array}$ \\
\hline Seabed lease & The Crown Estate Scotland & $\begin{array}{l}\text { Crown Estate Act } 1961 \\
\text { and The Scotland Act } \\
2016\end{array}$ & $\begin{array}{l}\text { The Crown Estate Scotland encourages any applicants to contact them before } \\
\text { applying for a lease to check whether the site is available. }\end{array}$ \\
\hline $\begin{array}{l}\text { Habitats regulations } \\
\text { appraisal (if } \\
\text { necessary) }\end{array}$ & $\begin{array}{l}\text { MS-LOT, Crown Estate } \\
\text { Scotland, relevant Local } \\
\text { Authority, Scottish } \\
\text { Environmental Protection } \\
\text { Agency }\end{array}$ & $\begin{array}{l}\text { The Conservation (Natural } \\
\text { Habitats, and c.) } \\
\text { Regulations } 1994\end{array}$ & $\begin{array}{l}\text { Scottish Natural Heritage are the advisory agency and if a Habitats Regulations } \\
\text { Appraisal is required, SNH must be consulted by the competent authority. }\end{array}$ \\
\hline None & $\begin{array}{l}\text { Scottish Natural Heritage } \\
\text { Scottish Police Force }\end{array}$ & $\begin{array}{l}\text { Wildlife and Natural } \\
\text { Environment (Scotland) } \\
\text { Act } 2011 \text {, } \\
\text { Wildlife and Countryside } \\
\text { Act } 1981\end{array}$ & $\begin{array}{l}\text { It is an offense to grow any plant species outside of its native range, including } \\
\text { seaweed. SNH provides guidance to the competent authority on whether the } \\
\text { activities applied for under a Marine License are compliant with these laws. }\end{array}$ \\
\hline $\begin{array}{l}\text { Works license policy } \\
2017\end{array}$ & Shetland Islands Council & $\begin{array}{l}\text { Zetland County Council } \\
\text { Act } 1974\end{array}$ & $\begin{array}{l}\text { A Work License is required from the Shetland Islands Council for the cultivation of } \\
\text { seaweed within the Shetland County Council Area. }\end{array}$ \\
\hline Planning permission & $\begin{array}{l}\text { Local Planning } \\
\text { Authority/Local Council }\end{array}$ & $\begin{array}{l}\text { Town and Country } \\
\text { Planning (Scotland) Act } \\
1997\end{array}$ & $\begin{array}{l}\text { Planning permission is required for any land side infrastructure such as new } \\
\text { slipways and drying facilities. }\end{array}$ \\
\hline
\end{tabular}

choice is made on the basis that the industry we are studying is not yet commercialized and we therefore cannot assess or observe the actions of the organizations running the operations, nor the audience (interested parties, stakeholder, or local communities).

Scharpf (1999) distinguishes between in-put and output legitimacy, where in-put legitimacy refers to procedure and participation and out-put legitimacy relates to consequences, problem-solving capacity and effectiveness (see also Bäckstrand et al., 2010). Some authors claim that if in-put legitimacy is high, this can increase the out-put legitimacy (see for instance Risse, 2004). Others argue that high out-put legitimacy can compensate for low in-put legitimacy (Sharpf, 1999). Dingwerth (2007) proposes four dimensions of out-put legitimacy: (1) policy effectiveness; (2) institutional effectiveness; (3) compliance effectiveness; and (4) environmental effectiveness. Although touching on out-put-legitimacy, our main focus as reasoned in the previous paragraph, is on the three dimensions of in-put legitimacy; (1) participation and inclusion; (2) democratic control and accountability; and (3) argumentative practice and deliberative quality (Bäckstrand et al., 2010).

Legitimacy assessments rest on a complex interplay between the decision-making processes and the out-put of these processes.
In practice, the dialectic relationship between in-put and output legitimacy makes it difficult to clearly distinguish between procedural and substantive sources of legitimacy (Connelly et al., 2006). Through concepts such as overall legitimacy (Bäckstrand et al., 2010; Birnbaum, 2015) and throughput legitimacy (Schmidt, 2013) scholars have tried to overcome the dichotomy between in-put and out-put legitimacy: "There is widespread agreement in scholarly literature that in-put and output legitimacy are closely connected and that legitimacy can neither be attained by inclusion nor by effectiveness alone" (Hogl et al., 2012, p. 14).

Our aim in this paper is not to discuss or emphasize the dichotomous aspects of legitimacy. Rather, the data has pointed us toward dimensions related to in-put legitimacy. Relating in-put legitimacy to our Scottish context, we ask if the policies and norms for seaweed cultivation are being developed in a transparent, fair, inclusive and accountable manner, and form effective institutions for problem-solving and performance. We focus mainly on how stakeholders would like the seaweed cultivation sector to develop, or in line with the legitimacy definition above: what actions are desirable, proper, or appropriate in the seaweed cultivation sector as perceived by stakeholders. Given that in-put legitimacy is geared to democratic principles, this article can be understood as 
TABLE 2 | Statements/opinions (concourse) on seaweed cultivation in Scotland chosen by the authors from the Q-sample.

\begin{tabular}{|c|c|c|c|}
\hline Environmental sustainability & Social sustainability & Economic sustainability & Institutional sustainability \\
\hline $\begin{array}{l}7 \text { Seaweed cultivation should take } \\
\text { place offshore }\end{array}$ & $\begin{array}{l}14 \text { Seaweed cultivators should } \\
\text { engage with local communities }\end{array}$ & $\begin{array}{l}4 \text { Seaweed cultivation in Scotland } \\
\text { should be developed for local markets }\end{array}$ & $\begin{array}{l}9 \text { Seaweed cultivators should } \\
\text { communicate with other users of the } \\
\text { sea }\end{array}$ \\
\hline $\begin{array}{l}10 \text { Environmental sustainability of } \\
\text { seaweed cultivation should be a } \\
\text { priority }\end{array}$ & $\begin{array}{l}19 \text { Seaweed cultivators should } \\
\text { provide transparent information about } \\
\text { farming techniques to the public }\end{array}$ & $\begin{array}{l}3 \text { Local economic benefits should be } \\
\text { put above nation-wide economic } \\
\text { benefits }\end{array}$ & $\begin{array}{l}12 \text { Co-operatives are a viable } \\
\text { development option for seaweed } \\
\text { cultivation companies }\end{array}$ \\
\hline $\begin{array}{l}15 \text { The current regulatory processes } \\
\text { for seaweed cultivation are fit for } \\
\text { purpose }\end{array}$ & $\begin{array}{l}8 \text { Seaweed cultivation should enrich } \\
\text { communities through traditional uses } \\
\text { and knowledge re-enforcement }\end{array}$ & $\begin{array}{l}5 \text { Seaweed cultivation in Scotland } \\
\text { should be developed to be globally } \\
\text { competitive }\end{array}$ & $\begin{array}{l}2 \text { Locally run small to medium scale } \\
\text { seaweed farms are the way forward }\end{array}$ \\
\hline $\begin{array}{l}17 \text { Seaweed cultivation should be } \\
\text { prioritized over other uses of the } \\
\text { marine environment }\end{array}$ & $\begin{array}{l}13 \text { Seaweed cultivation should } \\
\text { provide community benefits and local } \\
\text { jobs }\end{array}$ & $\begin{array}{l}6 \text { Seaweed cultivation in Scotland } \\
\text { should be developed for regional and } \\
\text { national markets }\end{array}$ & $\begin{array}{l}20 \text { Seaweed cultivators should rely on } \\
\text { regulators to establish best-practice } \\
\text { guidelines }\end{array}$ \\
\hline
\end{tabular}

a contribution in terms of giving voice to stakeholders and be a part of "the good argument" (Hogl et al., 2012). We do not argue that there is a direct link between a legitimate seaweed cultivation sector, little conflict and effective decision making. However, we do argue that it is key to understand stakeholders' perception to try to navigate these issues as best as possible, to realize the benefits of industry development and avoid the pitfalls.

Legitimacy is not observable as such, which makes it a challenge to directly measure. However, as a starting point we assume a link between the four pillars of sustainability and legitimacy for the seaweed cultivation sector. Based on this assumption, we have chosen statements for our Q method that represent the social, economic, environmental and institutional sustainability of the seaweed sector (Table 2). In the next section, we describe the four pillars of sustainability in relation to legitimacy, before describing our Q method approach in detail.

\section{Sustainability and Legitimacy}

The Scottish Government is supportive of Blue Growth, within the parameters of sustainability of environment, economy and society (The Scottish Government, 2019a). The concept of "sustainability" was launched in the "our Common Future" report (1987), defined as development that meets the needs of the present without compromising the ability of future generations to meet their needs. Over time, the concept has become holistic, including economic, social and institutional dimensions in addition to the environment. These dimensions are co-dependent, and Figure 2 is often used to illustrate this (Nofima, 2018).

Social sustainability is closely related to the social acceptability and legitimacy of an industry (Provasnek et al., 2017), in our case, seaweed cultivation.

In this paper we are primarily concerned with exploring the factors that stakeholders perceive as linked to legitimacy for seaweed cultivation. We argue that legitimacy there is a relationship between legitimacy for the industry and the four pillars of sustainability.

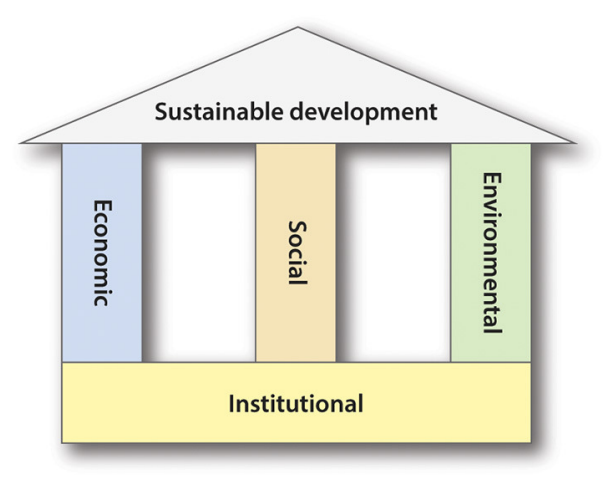

FIGURE 2 | The environmental, economic and social sustainability are the pillars, and the foundation is made of institutional sustainability, which consists of management and governance. After Nofima AS, inspired by University of York and Chemical Industries Association, 2005.

\section{Q METHODOLOGY}

Q-methodology is a technique developed in the 1930's (Stephenson, 1953) to explore individual phenomena such as opinions, perspectives and attitudes (Watts and Stenner, 2012). It is a way to investigate various views of a specific topic within a group, and it combines the strength of quantitative and qualitative research methods (Watts and Stenner, 2012). There are typically six phases to Q-method: (1) development of the concourse, (2) development of the Q-sample (statements), (3) development of the P set (informants), (4) the Q sort, (5) data analysis, and (6) interpretation.

The informants were asked to arrange the set of statementthe "Q-set" - across a normal distribution (bell curve) that indicates agreement/disagreement (see Figures 3-5 for example). We chose a relatively flat bell curve since the informants are knowledgeable about the issue at hand (Watts and Stenner). The selected group of informants ranked the statements in relation to one another, in this case from 4 to -4 . The result of each informants ranking is called the Q sort. Each Q sort was then 


\begin{tabular}{|c|c|c|c|c|c|c|c|c|}
\hline & & & \multirow{3}{*}{$\begin{array}{l}5 \\
6\end{array}$} & \multirow{3}{*}{$\begin{array}{c}19 \\
3 \\
4\end{array}$} & \multirow{3}{*}{$\begin{array}{l}11 \\
12\end{array}$} & \multirow[b]{3}{*}{9} & \multirow[b]{3}{*}{13} & \\
\hline & & & & & & & & \\
\hline & 1 & 17 & & & & & & \\
\hline 7 & 15 & 20 & 8 & 18 & 2 & 16 & 14 & 10 \\
\hline-4 & -3 & -2 & -1 & 0 & 1 & 2 & 3 & 4 \\
\hline
\end{tabular}

FIGURE 3 | Ideal sort for factor 1. Factor name was chosen based on statements 7 and 14. Color coding is based on the four pillars of sustainability (green $=$ biological sustainability, blue = economic sustainability, Red = social sustainability, and yellow $=$ institutional sustainability).

\begin{tabular}{|c|c|c|c|c|c|c|c|c|}
\hline & & & \multirow{3}{*}{$\begin{array}{l}7 \\
6\end{array}$} & \multirow{3}{*}{$\begin{array}{c}11 \\
9 \\
14\end{array}$} & \multirow{3}{*}{$\frac{13}{3}$} & \multirow[b]{3}{*}{2} & \multirow[b]{3}{*}{10} & \\
\hline & & & & & & & & \\
\hline & 1 & 17 & & & & & & \\
\hline 15 & 4 & 8 & 20 & 18 & 19 & 16 & 12 & 5 \\
\hline-4 & -3 & -2 & -1 & 0 & 1 & 2 & 3 & 4 \\
\hline
\end{tabular}

FIGURE 4 | Ideal sort for factor 2. Factor name was chosen based on statements 15 and 5 . Color coding is based on the four pillars of sustainability (green $=$ biological sustainability, blue = economic sustainability, Red = social sustainability, and yellow = institutional sustainability).

\begin{tabular}{|c|c|c|c|c|c|c|c|c|}
\hline & & & & 11 & & & & \\
\hline & & & 2 & 16 & 9 & & & \\
\hline & 1 & 17 & 6 & 4 & 12 & 19 & 10 & \\
\hline 15 & 18 & 7 & 3 & 5 & 8 & 14 & 20 & 13 \\
\hline-4 & -3 & -2 & -1 & 0 & 1 & 2 & 3 & 4 \\
\hline
\end{tabular}

FIGURE 5 | Ideal sort for factor 3. Factor name was chosen based on statements 15 and 13 . Color coding is based on the four pillars of sustainability (green = biological sustainability, blue = economic sustainability, Red = social sustainability, and yellow $=$ institutional sustainability).

analyzed using a software called PQmethod. We factor-analyzed the $\mathrm{Q}$ sorts to find a small number of ideal factors that capture an acceptable amount of the studys overall vector variance (Watts and Stenner, 2012). Hence, the narratives presented are derived using a statistical process (Principal Component Analysis) and are the products of any subset of the participants who revealed similar views through the distribution of the sorted statements (Donaldson and Eden, 2005). Each factor or narrative are hence "idealized sorts" and not necessarily the exact Q sort of any participant (Webler and Danielson, 2009). For this article, we chose a solution with three factors that represent groups of shared societal perspectives, and used automatic flagging. Finally, we analyzed each of the three factors in detail in order to write a descriptive narrative.

\section{Administering the $\mathbf{Q}$ Sort}

The aim of the concourse survey is to provide a comprehensive understanding of the range of opinions that exist on the topic at hand. This study forms part of the H2020 GENIALG project, where the Scottish Association for Marine Science is investigating the social acceptability of seaweed farming in several case studies across Europe, of which Scotland is one. Semi-structured interviews, workshops, and document analysis formed some of the activities in the Scottish case study (data was collected in 2017-2019). Based on the findings of these activities, the authors collected a large number of statements for the Q-sample. In order to reduce these to a manageable number that we could situate through rich contextual data, we used the four pillars of sustainability to sift them: environmental, social, economic and institutional sustainability. This resulted in 20 statements shown in Table 2.

Participants undertaking the $\mathrm{Q}$ sort were asked to talk through their opinions on individual statements, why they chose to rank them as they did, and open comments on the subject area. This approach arguably provides both theoretical and empirical observations. Setting the results within context and offering a narrative to underpin the factor (Webler and Danielson, 2009). It is necessary to 


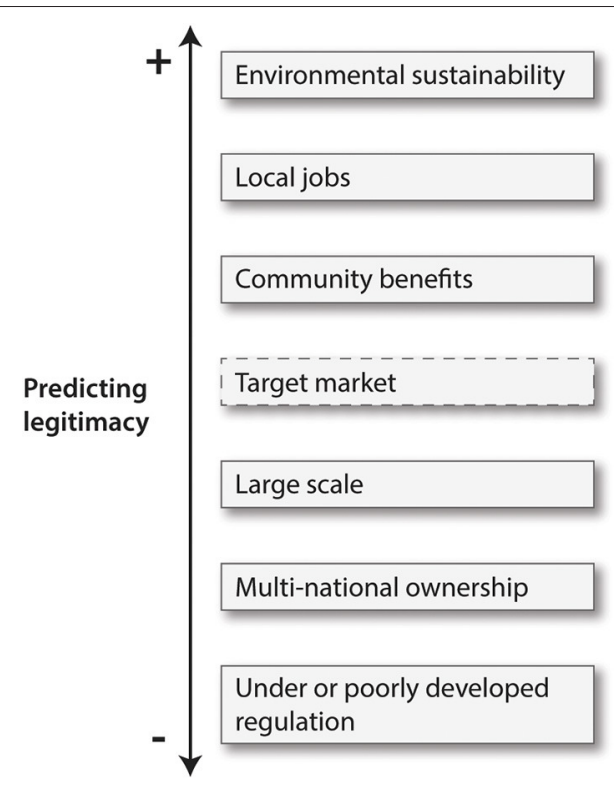

FIGURE 6 | Characteristics predicting a legitimate seaweed cultivation sector in Scotland, based on the results of all three factors. Boxes in black are likely to be less legitimate, boxes in gray are likely to be more legitimate, and the dashed line box shows the characteristics that is neutral.

define perspectives before conducting a survey to measure the frequency of occurrence of perspectives in a population (Webler and Danielson, 2009).

Since the respondents, or "P-Sample", are not selected in order to produce generalizable "patterns within and across individuals" (Barry and Proops, 1999, p. 339), a limited number of participants is acceptable and appropriate (Watts and Stenner, 2012). The number of participants $(N=16)$ fits within the standard of the literature (Webler and Danielson, 2009). The 16 participants chosen were relevant to the question as they were; (1) already involved in the seaweed cultivation or harvesting industry, are currently undertaking science on seaweed cultivation, or (2) are interested in starting up a seaweed cultivation business or service, or (3) are regulators, or are seaweed industry association representatives (see Table 3 ).

\section{FINDINGS}

As mentioned above, three distinct perspectives, or patterns, emerged from the factor analysis of the Q sort. Cumulatively, these explained $72 \%$ of the variance between the $16 \mathrm{Q}$ sorts, shown in Table $4(\mathrm{P} 1=25 \%, \mathrm{P} 2=25 \%, \mathrm{P} 3=22 \%)$.

We understand the three factors as discourses, and we analyzed these based on the "crib-sheet method" (Watts and Stenner, 2012). This means that while we focus on the distinguishing statements, which are those statements differing the most between the three discourses, we also address what the discourses agreed on, known as the consensus statements, as well as the statements in between. We give the three discourses titles based on their idealized sorts: (1) Environmental and social sustainability focus; (2) Economic and environmental sustainability with a global market focus and; (3) Social and institutional sustainability with local jobs as a priority. The Q sort value for each statement is found in Table 5.

\section{Factor 1-Environmental and Social Sustainability Focus}

Five participants significantly associated with this factor; one from science, one from regulation, one seaweed cultivator, and two from wild seaweed harvesting (Q Sort 1, 2, 4, 8, 12). The main focus of this factor is environmental sustainability and social responsibility with a strong emphasis on local jobs and communication with local communities and other marine users by seaweed cultivation companies. This factor disagrees most strongly with the statement that seaweed cultivation should take place off-shore. It also feels that the current regulatory regime is not fit for purpose, however participants were aware of ongoing efforts to improve regulation and regulatory agencies knowledge of the industry. This factor is neutral about issues related to economics and comparisons between seaweed and finfish cultivation.

\section{Factor 2-Economic and Environmental Sustainability With a Global Market Focus}

The interviewees that represent factor two are three community representatives, one from science, and one seaweed company (Q Sort 3, 5, 10, 11, and 13). Factor two is very critical of the regulatory regime as it is perceived as slow and embryonic, with the regulators taking too much time to make decisions. This is the only factor that feels strongly that seaweed cultivation should focus on global markets, supplied by small to medium scale, locally run farms. Communication, collaboration and education featured heavily in discussion about why the participants disagreed with seaweed cultivation run on a large scale by multinational companies or offshore and being prioritized over other uses of the sea. This factor is the one that is spread the most across the four pillars of sustainability and is also the only factor that feels strongly about economic aspects.

\section{Factor 3-Social and Institutional Sustainability With Local Jobs as a Priority} This factor is made up of participants from supply-chain/service sectors (Q Sort 6, 7, 9, and 15). That participants feel very strongly that seaweed cultivation should focus on community benefits and local jobs, through an industry which is socially and environmentally sustainable. Linked to this, factor three strongly disagrees that large-scale seaweed farms run by multinational companies is the way forward. Equally, this factor does not agree that markets should be constrained, but rather they should develop where there is demand, whether that be local, regional, national, or international so long as it provides local jobs. Despite not scoring communication and transparency as highly as possible it was a running theme throughout the comments about the statements. This factor, like all of the others, thinks that environmental sustainability is central and does not think that the current regulatory regime is fit for purpose. 
TABLE 3 | Overview of participants per sector.

\begin{tabular}{llllc}
\hline $\begin{array}{l}\text { Community } \\
\text { representatives }\end{array}$ & Science & Regulation & Harvesting & $\begin{array}{c}\text { Seaweed cultivation } \\
\text { company }\end{array}$ \\
\hline 5 & 2 & 1 & 2 & 2 \\
\hline
\end{tabular}

In the idealized q sort, 5 community representatives, 2 scientists, 1 regulator, 2 from harvesting sector, 2 seaweed cultivation companies and 4 from the supply chain/service sector were flagged by the automatic flagging in PQ method.

\section{Cross-Factor Consensus}

Statements that were not ranked significantly differently between perspectives are termed areas of consensus. Four statements were non-significant for all perspectives at $p>0.05$, as seen in Table 6. This means that the three factors felt similarly about the statement, both in terms of agreeing or disagreeing. It is clear that large-scale seaweed farms run by multi-national companies and limiting industry development to regional and national markets is not the optimal way forward according to all factors. Likewise, all factors agreed strongly that the environmental sustainability of seaweed cultivation should be a priority. Participants described the responsibility of this priority as being shared between cultivators and regulators, with an emphasis on collaboration between the two. This was to ensure there is enough knowledge to develop an efficient system for both regulation and good practice. There was variation across the participants as to whether good practice should be enforced by regulators, led by industry, or a mix of both. Some of the participants suggested that good practice is linked with social acceptability and in one case, the term "social license" was used.

\section{WHAT COULD A SUCCESSFUL SEAWEED CULTIVATION SECTOR LOOK LIKE?}

In the interests of brevity, the following section explores the most prominent and contextually relevant of our results in relation to the four pillars of sustainability and our legitimacy framework. It should be noted that there is not a specific section focusing on social sustainability, as it was found to be inextricable linked with environmental, economic, and institutional sustainability and is therefore interwoven throughout the sections in our discussion. The difficulty of defining the characteristics of the pillar of social sustainability as distinct from the other pillars within the context of seaweed cultivation in Scotland, is evident.

\section{The Social Importance of Environmental Sustainability}

Across all factors, participants disagreed strongly with the statement that "The current regulatory processes for seaweed cultivation are fit for purpose". When we categorized the statements in Table 2, this one was placed under the "environmental pillar" of sustainability, as we assumed that the regulations would lead to environmental sustainability. However, the Q sorting revealed differences in the interpretation of the issue.

Factor 1 (environmental and social sustainability focus) disagrees with the statement as participants perceive that there is
TABLE 4 | Factor matrix (Q sort results) where "X" indicates a defining sort using automatic flagging in $P Q$ method.

\begin{tabular}{|c|c|c|c|c|}
\hline \multirow[b]{2}{*}{ Q sor } & \multirow[b]{2}{*}{ Stakeholder } & \multicolumn{3}{|c|}{ Factors } \\
\hline & & 1 & 2 & 3 \\
\hline 1 & Science & $0.7504 X$ & 0.3158 & 0.0461 \\
\hline 2 & Harvester & $0.8054 X$ & 0.1711 & 0.3792 \\
\hline 3 & Science & 0.5045 & $0.5724 X$ & 0.0928 \\
\hline 4 & Regulation & $0.5786 X$ & 0.3915 & 0.3518 \\
\hline 5 & Community representative & 0.2558 & $0.6704 X$ & 0.2270 \\
\hline 6 & Supply-chain & 0.1939 & 0.0809 & $0.8520 \mathrm{X}$ \\
\hline 7 & Supply-chain & 0.0587 & 0.4332 & $0.5022 X$ \\
\hline 8 & Seaweed cultivation company & $0.7188 \mathrm{X}$ & 0.2291 & 0.5153 \\
\hline 9 & Supply-chain & 0.2110 & 0.5033 & $0.7317 X$ \\
\hline 10 & Community representative & 0.2921 & $0.8009 x$ & 0.0540 \\
\hline 11 & Community representative & 0.1752 & $0.8259 X$ & 0.1859 \\
\hline 12 & Harvester & $0.6815 X$ & 0.3513 & 0.2898 \\
\hline 13 & Seaweed cultivation company & 0.2395 & $0.8112 X$ & 0.3051 \\
\hline 14 & Community representative & 0.4582 & 0.5203 & 0.5155 \\
\hline 15 & Supply-chain & 0.3618 & 0.1584 & $0.8196 x$ \\
\hline 16 & Community representative & $0.6938 X$ & 0.1373 & 0.5795 \\
\hline & $\%$ expl. variance & 25 & 25 & 22 \\
\hline
\end{tabular}

currently no effective regulatory process. Prominent reasons for this perspective included marine licensing being viewed as too broad to be an efficient mechanism for regulation and that there is currently no testing of cultivated or harvested seaweeds (for heavy metals, contaminants etc.) bound for human consumption markets (Wood et al., 2017). Most participants noted that the regulations are based on other industries rather than specific knowledge of seaweed cultivation, advising that this is a recipe for social and environmental issues. Factor 2 (economic and environmental sustainability with a global market focus) bases their disagreement with the statement on the complexity of the situation, arguing that where there is work underway between the regulators and cultivators, it is viewed as "not there yet". Put differently, the participants stated that regulation is embryonic, decision-making is slow, and not suitable for seaweed cultivation. Finally, Factor 3 (social and institutional sustainability with local jobs as a priority) disagrees because the participants had not heard of any regulatory processes and are therefore assumed that there are not any or they are not adapted to seaweed cultivation.

There was acknowledgment across the factors that regulators are making an effort to learn, but also that cultivators have an opportunity to develop good-practice that goes above and beyond 
TABLE 5 | Factor Q sort values for each statement.

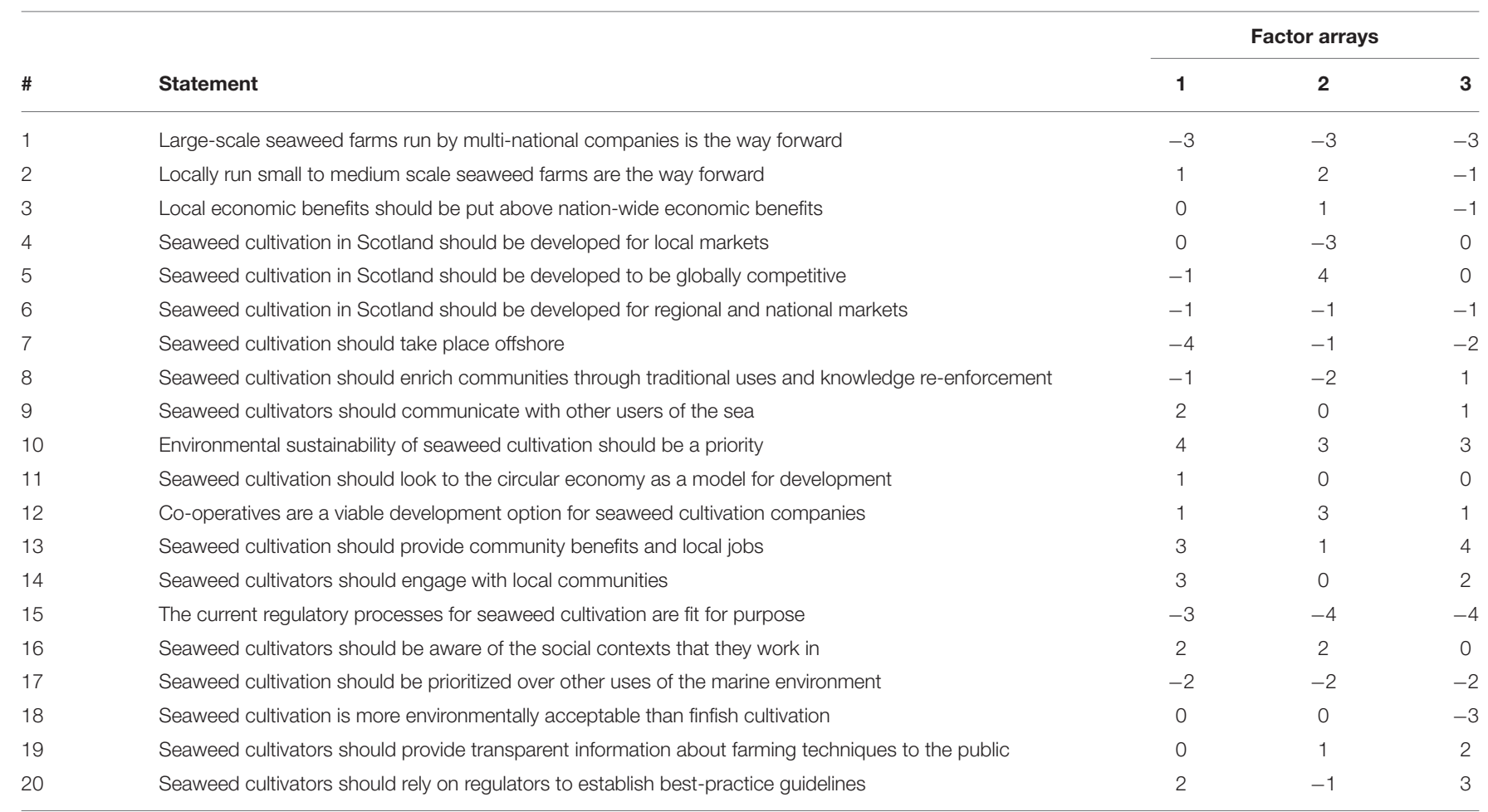

TABLE 6 | Agreement across factors: those statements that do not distinguish between any pair of factors.

\begin{tabular}{|c|c|c|c|c|}
\hline \# & Statement & \multicolumn{3}{|c|}{ Factor arrays } \\
\hline 6 & Seaweed cultivation in Scotland should be developed for regional and national markets & -1 & -1 & -1 \\
\hline 10 & Environmental sustainability of seaweed cultivation should be a priority & 4 & 3 & 3 \\
\hline 17 & Seaweed cultivation should be prioritized over other uses of the marine environment & -2 & -2 & -2 \\
\hline
\end{tabular}

Those listed here at the statements that are non-significant at $P>0.05$.

the law. When exploring this in terms of sustainability and legitimacy, the perception of lack of institutional effectiveness is perceived as a barrier to seaweed cultivation. However, we also see how the in-put end of legitimacy (that is participation, deliberation, and control) is potentially being constructed through willingness to learn and collaborate between regulators and cultivators.

All factors agree that "Environmental sustainability of seaweed cultivation should be a priority". Participants in Factor 1, which rate this statement at 4 , reasoned that there "is no logical reason why it can't be [environmentally sustainable]", that it would be beneficial to have a form of aquaculture that has net positive environmental impact, and that both of these considerations will improve the social acceptability of the industry. Factor 2 rates this statement at 3 . However, the reasoning provided by stakeholders for their choice was based on morality: "it will keep me awake at night if it is not sustainable;" "it's about bringing people along with the industry and that will only happen if it is sustainable;" "to ignore environmental sustainability is madness".
Moral legitimacy, as defined by Suchman (1995) is "sociotrophic" -in other words, is based on "the right thing to do", reflecting the values and beliefs of the individual as well as socially constructed norms. In this case, moral legitimacy could be linked with input legitimacy, given the former has been related to procedure and process (Weber, 1971 in Suchman, 1995). Factor 3 also rated this statement at 3 . One stakeholder made an important point about the current emergent state of the seaweed cultivation industry in Scotland and the opportunities this position presents for sustainable development, best described in their own words:

\footnotetext{
"Agriculture and aquaculture should strive for environmental sustainability. Here there is the opportunity for seaweed cultivation to have a positive impact on the environment if it's done correctly and we keep an eye on genetics and diseases. What is the point if it isn't? Seaweed cultivation in Scotland is in the privileged position not to have engrained poor environmental standards, if you start off from the perspective of environmental sustainability then it sets a good baseline to develop from."
} 
All factors disagree that "Seaweed cultivation should be prioritized over other uses of the sea". The reasons behind this disagreement were very similar and can be summarized as; the sea has too many uses and is important to too many people to have seaweed cultivation as a priority. We postulate that this view is related to seaweed cultivation being a new "player" in the coastal zone, hence, it does not take priority over other more traditional uses such as fishing or even farming salmon. Interestingly, both Factors 1 (environmental and social sustainability focus) and 2 (economic and environmental sustainability with a global marked focus) are neutral about the statement "Seaweed cultivation being more environmentally acceptable than finfish", while Factor 3 (social and institutional sustainability with local jobs as a priority) disagrees quite strongly with this. The differences in opinion around this statement are related to the trade-offs that finfish aquaculture represents in Scotland. On the one hand, offering full time jobs and economic potential in rural coastal areas, and on the other causing environmental impacts (Galparsoro et al., 2020).

Despite variation in reasoning and in some cases values, there is a shared desire across all factors and individual participants, that seaweed cultivation should be developed to have as little impact on the environment as possible. Further, that environmental sustainability offers pathways to legitimacy for the industry as it was perceived to be a key component of decision-making (opposing or supporting developments) by local communities, other users of the sea and interested parties.

\section{Institutional Sustainability and the Issue of Scale}

Across all factors, stakeholders disagree strongly with the statement "large-scale seaweed farms run by multi-national companies is the way forward". This is unsurprising, given the current context of media scrutiny into multi-national owned finfish aquaculture (Billing, 2018), and the Scottish Government Seaweed Cultivation Policy Statement (focusing on small and medium scale farms) (The Scottish Government, 2017). Factors 1 and 2 argued that a large-scale model would defeat the point of environmental sustainability and would lead to less community benefits, and contribute less to rural coastal development. Many of the participants provided the example of salmon farming as a negative association between large corporations and sustainability goals. Nevertheless, resigned pragmatism was evident in participant perceptions as they note that these types of companies have capital, and therefore advised that the largescale model might in fact, be the way that seaweed cultivation does develop. Interestingly, Factor 3's disagreement with this statement was on the same basis as the other two but diverged through the perception it is difficult to hold multi-national companies accountable for any negative actions or impacts (either social or environmental). The same participants argued that the industry should develop at the scale necessary (be it small, medium or large scale), but monopolies on any level are undesirable and damaging to local communities. From these perspectives, it could be argued that large-scale seaweed cultivation is seen as economically legitimate, but not socially or environmentally legitimate.

The issue of scale is therefore perceived as institutional and relates to all pillars of sustainability. Who should be allowed to cultivate seaweed and at what scale is seen as having an impact on (1) local benefits, (2) jobs, and (3) environment. This means that the institutional and regulatory structure of the seaweed cultivation industry should, at the least, recognize that local perceptions of a legitimate industry are not likely to stretch to large-scale, multi-national ownership. In turn, this understanding should inform the approach of those who embark on commercial-scale seaweed cultivation in Scotland, where the three attributes listed above should be at the forefront of goodpractice, operational strategies, and communication with local communities, other users of the sea and interested parties.

\section{Economic Sustainability and Which Market to Target}

All factors disagree on the statement "Seaweed cultivation in Scotland should be developed for regional and national markets". However, they do not feel strongly about it, rating it at -1 . Stakeholders in Factor 1 had some reservations as they think that the industry should not exclude international markets, but should not be wholly focused on them either. Stakeholders in Factor 2 focused on the current lack of local and regional markets, advising that tapping into already developed markets could provide the opportunity for innovative, high value products. Linked with this is the perception (and evidence seen here: Scotland Food Drink, 2018) that seafood branded as "Scottish" is increasingly competitive in international markets. Factor 3 argues that since the national market is quite small or underdeveloped, any market should be developed as long as there is enough demand. In sum, all factors think that there is a need to balance local, regional, national, and international markets (economic sustainability) with local jobs and community benefits (social sustainability) and environmental sustainability.

\section{PREDICTING LEGITIMACY FOR SEAWEED CULTIVATION}

Sustainable blue growth in coastal and marine areas in line with the stated objectives of Scotland's National Marine Plan (Marine Scotland, 2015) raises new challenges and demands. Such growth will increase the number and variety of activities and hence the spatial and temporal diversity and number of stakeholders in the coastal zone. In our study, we have investigated how the new industry of seaweed cultivation in the Scottish coastal zone should develop, as perceived by a wide variety of relevant stakeholders. We have linked the concept of legitimacy with the four pillars of sustainability, to further investigate what this perception will entail for future management. Our results show a diverse range of characteristics that stakeholders emphasize as most important regarding sustainability. However, it is also evident that stakeholders share some views on what a "successful" seaweed sector would look like. 
We see that the factors agree that the top priority for seaweed cultivation is to ensure it develops in an environmentally sustainable way, and that a small-scale approach with a focus on the local benefits such as job creation is more desirable than a large-scale approach. Moreover, there is a general consensus that production should be for all markets, even if the reasoning behind this view differs across factors. We found that there is a general agreement that the regulatory processes are not fit for purpose, and further discussion with participants suggests that in their current form, they are an obstacle for effective management. We also want to underline that while communication and transparency does not score very highly in the Q sort it was a running theme throughout conversations with participants about the statements.

There are also some diverging views, and here we will only point to the most relevant. To Factor 1 (environmental and economic sustainability focus) environmental and economic sustainability is less important for developing the sector in a legitimate manner than local social benefits. For Factor 2 (economic and environmental sustainability with a global market focus), seaweed cultivation in Scotland should be developed to be globally competitive, at the same time as prioritizing social sustainability through local scale cultivation and business models that support is the way forward (e.g., co-operatives). The overall priority of Factor 2 is environmental and economic legitimacy. This is also the only factor that rates the economic aspects of seaweed cultivation as important relative the other statements. Factor 3 (social and institutional sustainability with local jobs as a priority) is mostly concerned with issues relating to social and institutional legitimacy, where local jobs and robust regulation are viewed as key.

As this is a new industry, there is little empirical evidence about its legitimacy regarding both processes (in-put) for seaweed cultivation and the effectiveness (out-put) of the different dimensions. What we find in our analysis is that there are both shared and diverging viewpoints about how seaweed cultivation should develop in the future in order to be legitimate and, arguably, more effective and sustainable. In line with (Raadgever et al., 2008) we argue that this overview of stakeholders' perspectives can be useful for the development of seaweed cultivations as it can help to; (a) set the research agenda; (b) identify differences in values and interests that need to be discussed; (c) create awareness of issues among a broad range of stakeholders; and (d) characterize potential development scenarios. This last statement is especially true in the context of seaweed cultivation in Scotland as it is an emergent industry that holds a lot of promise, but also has some potential pitfalls (Cottier-Cook et al., 2016). In this article we have pointed to some key issues that can improve the overall legitimacy of seaweed cultivation (Figure 6). This research suggests that a successful seaweed industry is perceived as one that is environmentally and socially sustainable, where local benefits and local jobs are key. We found there is potential to improve the current regulatory processes in place for seaweed cultivation in Scotland, which could empower those who want to diversify into it, at the same time as improving trust in the industry for those who are skeptical.

\section{Implications for Theory and Practice for Sustainable Seaweed Cultivation}

Reaching national blue growth goals within the framework of sustainable development, can be hampered if regional and local social contexts are not accounted for (Hersoug, 2013; Rybråten et al., 2018; Osmundsen et al., 2020). As such, it is important to recognize that the coastal zone is far from empty, with several sectors, uses and users vying for space at any one time. As seaweed cultivation is a nascent industry in the North Atlantic, with much touted potential for various sustainable value-chains (e.g., pharmaceuticals, nutraceuticals, biofuel, bioplastics, to name a few) (Van den Burg et al., 2019), characterizing the potential for it to be perceived as legitimate by a diverse range of key stakeholders, is an important issue to explore. However, studies on stakeholder perceptions are typically based on qualitative data (Barry and Proops, 1999; Bjørkan and Veland, 2019) which to some, especially the natural sciences, industry and regulators who are traditionally trained in quantitative approaches can be vague and diffuse (see for instance Law, 2004). To address this issue of language and understanding across disciplines and sectors, we used Q method in a novel way, combining rich qualitative narrative, with quantitative data, set within the four pillars of sustainability. We hope that this can help more disciplines draw clear lines of understanding between sustainability and perceived legitimacy of coastal activities to stakeholders, and strategies for developing legitimacy for blue growth industries. Hence, we suggest that Qmethod, styled in this way, is an approach that has the potential to increase positive impact of qualitative studies by making them more approachable to those outside the social scientific community. This is not a critique of qualitative methods, rather, an understanding that in order to contribute to the solutions to real-life problems, we must find a way to communicate across disciplines and sectors. Simply put, Q allows us to pinpoint issues that will generate areas of consensus and conflict, providing a fundamental understanding of stakeholder perceptions of how blue growth sectors should develop.

\section{DATA AVAILABILITY STATEMENT}

The raw data supporting the conclusions of this article will be made available by the authors, without undue reservation.

\section{ETHICS STATEMENT}

Ethical review and approval was not required for the study on human participants in accordance with the local legislation and institutional requirements. Written informed consent for participation was not required for this study in accordance with the national legislation and the institutional requirements.

\section{AUTHOR CONTRIBUTIONS}

MB led the conceptualization, methodological development, and use of software for the article (PQ method). S-LB realized the Q-sorting interviews in Scotland. Both 
authors analyzed the findings and wrote the article. All authors contributed to the article and approved the submitted version.

\section{FUNDING}

The authors would like to acknowledge the funding provided to the GENIALG project through the European Union's Horizon 2020 Framework Programme under Grant Agreement No. 727892 and MacroFuels project through the European Union's Horizon 2020 research and innovation programme

\section{REFERENCES}

Argyll and Bute Council (2017). News from Argyll and Bute Economic Development and Strategic Transportation Service. Transformation. 3. Available online at: https://www.argyll-bute.gov.uk/sites/default/files/autumn_2017_v2. pdf (accessed February 2, 2022).

Bäckstrand, K., Khan, J., Kronsell, A., and Lövbrand, E. (2010). Environmental Politics and Deliberative Democracy: Examining the Promise of New Modes of Governance. Massachusetts: Elvar Edgar Publishing. doi: $10.4337 / 9781849806411$

Bak, U. G., Mols-Mortensen, A., and Gregersen, O. (2018). Production method and cost of commercial-scale offshore cultivation of kelp in the Faroe Islands using multiple partial harvesting. Algal Res. 33, 36-47. doi: $10.1016 /$ j.algal.2018.05.001

Barry, J., and Proops, J. (1999). Seeking sustainability discourses with Q methodology. Ecol. Econ. 28, 337-345.

Billing, S. (2018). Using public comments to gauge social licence to operate for finfish aquaculture: lessons from Scotland. Ocean Coast. Manag. 165, 401-415. doi: 10.1016/j.ocecoaman.2018.09.011

Birnbaum, S. (2015). Environmental co-governance, legitimacy, and the quest for compliance: when and why is stakeholder participation desirable? J. Environ. Policy Plan. 18, 306-323. doi: 10.1080/1523908X.2015.1077440

Bjørkan, M. (2011). Fishing for advice - the case of the Norwegian fishing fleet (PhD thesis). University of Tromsø, Faculty of Biosciences, Fisheries and Economics, Norwegian College of Fisheries Science, Norway.

Bjørkan, M., and Veland, S. (2019). Beyond consensus: Perceptions of risk from petroleum developments in Lofoten, Vesterålen, and Senja, Norway. ICES J. Mar. Sci. 76, 1393-1403. doi: 10.1093/icesjms/fsz056

Brooker, E. E., Hopkins, C. R., Devenport, E., Greenhill, L., and Duncan, C. (2019). Civil society participation in the Scottish marine planning process and the role of Environmental Non-Governmental Organisations. J. Environ. Plann. Manag. 62, 2101-2123. doi: 10.1080/09640568.2018. 1532876

Burrows, M., and Fox, C., Moore, P., Smale, D., Greenhill, L., Martino, S. (2018). Wild Seaweed Harvesting as a Diversification Opportunity for Fishermen: A Report for Highlands and Islands Enterprise. Available online at: http://eprints.whiterose.ac.uk/137123/1/02376_WildWeed_Report_Clean_ Issue.pdf (accessed February 2, 2022).

Campbell, I., and Macleod, A., Sahlman, C., Neves, L., Funderud, J., Overland, M. et al. (2019). The environmental risks associated with the development of seaweed farming in Europe - prioritizing key knowledge gaps. Front. Marine Sci. 6, e00107. doi: 10.3389/fmars.2019.00107

Connelly, S., Richardson, T., and Miles, T. (2006). Situated legitimacy: deliberative arenas and the new rural governance. J. Rural Stud. 22, 267-277. doi: 10.1016/j.jrurstud.2005.11.008

Cottier-Cook, E. J., Nagabhatla, N., Badis, Y., Campbell, M. L., Chopin, T., Dai, W. et al. (2016). Policy Brief: Safeguarding the Future of the Global Seaweed Aquaculture Industry. Available online at: https://www.sams.ac.uk/t4-media/ sams/pdf/PB21.06---GSSTAR_FINAL.pdf (accessed February 2, 2022).

Dingwerth, K. (2007). The New Transnationalism: Transnational Governance and Democratic Legitimacy. Basingstoke: Palgrave Macmillan. under Grant Agreement No. 654010; and the Norwegian Research Council HAVBRUK2 under Grant Agreement No. 267946.

\section{ACKNOWLEDGMENTS}

The authors would like to thank Dr. Philip Kerrison, Dr. Arlene Ditchfield, Dr. Adrian Macleod, and Dr. Kati Michalek for their assistance in creating the Q concourse (stakeholder workshops) and providing their expert advice on all things related to seaweed cultivation.

Donaldson, A., and Eden, S. (2005). Structuring subjectivities? Using Q methodology in human geography. Area. 37, 413-422. Available online at: https://www.jstor.org/stable/20004480

FAO (2018). The State of Fisheries and Aquaculture in the world 2018, FAO. Org. Available online at: http://www.fao.org/state- of-fisheries-aquaculture (accessed February 2, 2022).

Froehlich, H. E., Afflerbach, J. C., Frazier, M., and Halpern, B. S. (2019). Blue growth potential to mitigate climate change through seaweed offsetting. Curr. Biol. 29, 3087-3093. doi: 10.1016/j.cub.2019.07.041

Galparsoro, I., Murillas, A., Pinarbasi, K., Sequeira, A. M., Stelzenmüller, V., Borja, Á., et al. (2020). Global stakeholder vision for ecosystem-based marine aquaculture expansion from coastal to offshore areas. Rev. Aquacult. 12, 20612079. doi: $10.1111 /$ raq. 12422

Hersoug, B. (2013). "The battle for space - the position of norwegian aquaculture in integrated coastal zone planning," in Global Challenges in Integrated Coastal Zone Management, eds E. Moksness, E. Dahl and J. Støttrup (John Wiley and Sons). doi: 10.1002/9781118496480.ch12

Hogl, K., Kvarda, E., Nordbeck, R., and Pregernig, M. (2012). Legitimacy and Effectiveness of Environmental Governance: Concepts and Perspectives. Available online at: https://www.researchgate.net/publication/261707801_Legitimacy_ and_effectiveness_of_environmental_governance_concepts_and_perspectives (accessed February 2, 2022).

Jentoft, S. (2000). Legitimacy and disappointment in fisheries management. Marine Policy 24, 141-148. doi: 10.1016/S0308-597X(99)00025-1

Law, J. (2004). After Method: Mess in Social Science Research. New York, NY: Routledge.

Marine Scotland (2012). Strategic Environmental Assessment (SEA) Scoping Report Seaweed; Policy Statement. Available online at: https://www2.gov.scot/seag/ seagDocs/SEA-00715/12730.pdf (accessed February 2, 2022).

Marine Scotland (2015). Scotland's National Marine Plan: A Single Framework for Managing Our Seas. Available online at: http://www.gov.scot/Publications/ 2015/03/6517/0 (accessed February 2, 2022).

Nofima (2018). Utvikling av barekraftportal for norsk havbruk [Development of a Sustainability Portal for Norwegian Aquaculture]. Report 35/28. Faglig sluttrapport Kine Mari Karlsen, Ulf Winther (SINTEF Ocean), Roy Robertsen, Eirik Mikkelsen and Roger Richardsen (SINTEF Ocean).

Osmundsen, T, C., Amundsen, V. S., Alexander, K. A., Asche F., Bailey, J., Finstad, B., et al. (2020). The operationalisation of sustainability: Sustainable aquaculture production as defined by certification schemes. Glob. Environ. Change. 60, 102025. doi: 10.1016/j.gloenvcha.2019.1 02025

Provasnek, A. K., Sentic, A., and Schmid, E. (2017). Integrating eco-innovations and stakeholder engagement for sustainable development and a social license to operate. Corp. Soc. Respon. Environ. Manag. 24, 173-185. doi: 10.1002/csr. 1406

Raadgever, G. T., Mostert, E., and van de Giesen, N. C. (2008). Identification of stakeholder perspectives on future flood management in the Rhine basin using Q methodology. Hydrol. Earth Syst. Sci. 12, 1097-1109 doi: 10.5194/hess-12-1097-2008

Risse, T. (2004). Global governance and communicative action. Govern. Oppos. 39, 288-313. doi: 10.1111/j.1477-7053.2004.00124.x 
Rybråten, S., Bjørkan, M., Hovelsrud, G.K., and Kaltenborn, B. P. (2018). Sustainable coasts? Perceptions of change and livelihood vulnerability in Nordland, Norway. Loc. Environ. 23, 1156-1171. doi: 10.1080/13549839.2018.1533931

Scharpf, F. W. (1999). Governing in Europe: Effective and Democratic? New York, NY: Oxford University.

Schmidt, V. A. (2013). Democracy and legitimacy in the European Union revisited: In-put, output and 'throughput'. Political Stud. 61, 2-22. doi: $10.1111 /$ j.1467-9248.2012.00962.x

Scotland Food and Drink (2018). Industry Performance Review 2018. Available online at: http://clients1.ibisworld.com/reports/us/industry/ currentperformance.aspx?entid=5715\#KED (accessed February 2, 2022).

Scottish Parliament. (2018). Scottish Crown Estate Bill. Available online at: https:// www.parliament.scot/bills-and-laws/bills/scottish-crown-estate-bill (accessed February 2, 2022).

Smale, D. A., Burrows, M. T., More, P., O'Connor, N., and Haekins, S. J. (2013). Threats and knowledge gaps for ecosystem services provided by kelp forests: a northeast Atlantic perspective. Ecol. Evol. 3, 4016-4038. doi: 10.1002/ece3.774

Stephenson, W. (1953). Q-technique and its Methodology. Chicago IL, The University of Chicago Press.

Suchman, M. C. (1995). Managing legitimacy: strategic and institutional approaches. Acad. Manag. Rev. 20, 571-610. doi: $10.5465 / \mathrm{amr} .1995 .9508080331$

The Scottish Government (2017). Seaweed Cultivation Policy Statement. Available online at: http://www.gov.scot/Resource/0051/00515518.pdf (accessed February 2, 2022).

The Scottish Government (2019a). Marine and Coastal Economy and Communties. Available online at: https://economicactionplan.mygov.scot/place/marineand-coastal/ (accessed November 7, 2019).

The Scottish Government (2019b). Seaweed Review. Available online at: https://www2.gov.scot/Topics/marine/seamanagement/seaweedrev (accessed November 5, 2019).

Van den Burg, S. W. K., Dagevos, H., and Helmes, R. J. K. (2019). Towards sustainable European seaweed value chains: a triple P perspective. ICES J. Marine Sci. 78, efsz183. doi: 10.1093/icesjms/fsz183

Van den Burg, S. W. K., Van Dejuin, A. P., Bartelings, H., et al. (2016). The economic feasibility of seaweed production in the North Sea. Aquacult. Econ. Manag. 20, 235-252. doi: 10.1080/13657305.2016.1177859
Watts, S., and Stenner, P. (2012). Doing Q Methodological Research: Theory, Methodology and Interpretation. London: Sage Publications Ltd.

Weber, M. (1946). From Max Weber, tr, eds. H. H. Gerth and C. Wright Mills. New York, NY: Free Press.

Weber, M. (1971). Makt og byråkrati: essays om politikk og klasse, samfunnsforskning og verdier. Oslo, Gyldendahl.

Webler, T., and Danielson, S. (2009). Using Q Method to Reveal Social Perspectives in Environmental Research. p. 1-53. Available online at: https://www.researchgate.net/publication/273697977_Using_Q_Method_to_ Reveal_Social_Perspectives_in_Environmental_Research (accessed February 2, 2022).

Wilson, D. C. (2009). Paradoxes of Transparency -Science and the Ecosystem Approach to Fisheries Management in Europe. Amsterdam: Amsterdam University Press.

Wood, D., Caluzzo, E., Kirby, D., Mooney-McAuley, K., and Kerrison, P. (2017). UK macroalgae aquaculture: what are the key environmental and licensing considerations? Marine Policy. 83, 29-39. doi: 10.1016/j.marpol.201 7.05 .021

Conflict of Interest: The authors declare that the research was conducted in the absence of any commercial or financial relationships that could be construed as a potential conflict of interest.

Publisher's Note: All claims expressed in this article are solely those of the authors and do not necessarily represent those of their affiliated organizations, or those of the publisher, the editors and the reviewers. Any product that may be evaluated in this article, or claim that may be made by its manufacturer, is not guaranteed or endorsed by the publisher.

Copyright (๑) 2022 Bjørkan and Billing. This is an open-access article distributed under the terms of the Creative Commons Attribution License (CC BY). The use, distribution or reproduction in other forums is permitted, provided the original author(s) and the copyright owner(s) are credited and that the original publication in this journal is cited, in accordance with accepted academic practice. No use, distribution or reproduction is permitted which does not comply with these terms. 